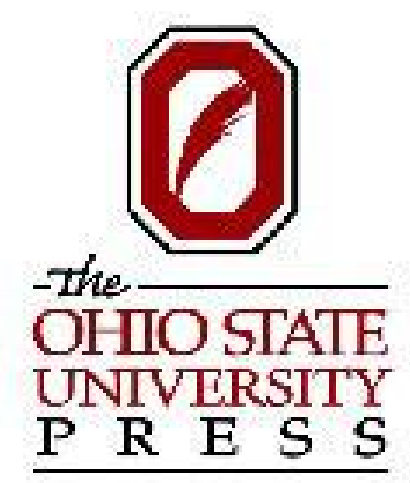

\title{
Institutionalization of Service Learning in Higher Education
}

Author(s): Robert G. Bringle and Julie A. Hatcher

Source: The Journal of Higher Education, Vol. 71, No. 3 (May - Jun., 2000), pp. 273-290

Published by: Ohio State University Press

Stable URL: http://www.jstor.org/stable/2649291

Accessed: 12-04-2016 18:38 UTC

Your use of the JSTOR archive indicates your acceptance of the Terms \& Conditions of Use, available at

http://about.jstor.org/terms

JSTOR is a not-for-profit service that helps scholars, researchers, and students discover, use, and build upon a wide range of content in a trusted digital archive. We use information technology and tools to increase productivity and facilitate new forms of scholarship. For more information about JSTOR, please contact support@jstor.org.

Ohio State University Press is collaborating with JSTOR to digitize, preserve and extend access to The Journal of Higher Education 


\section{‡ Robert G. Bringle Julie A. Hatcher}

\section{Institutionalization of Service Learning in Higher Education}

\section{Introduction}

Service is often included in the mission statement of institutions of higher education, but the importance of service is seldom as evident in their work as are teaching and research (Holland, 1997). There is, however, a revival of interest in the role that service can assume in higher education. Critical examinations have suggested ways in which greater emphasis on the scholarship of service can change the nature of faculty work, enhance student learning, better fulfill campus mission, and improve town-gown relations (e.g., Boyer, 1994, 1997; Bringle, Games, \& Malloy, 1999; Eggerton, 1994; Harkavy \& Puckett, 1994; Rice, 1996). The late Ernest Boyer stressed that higher education should develop scholarship connected to and integrated with community service. He noted,

The academy must become a more vigorous partner in the search for answers to our most pressing social, civic, economic, and moral problems, and must reaffirm its historic commitment to what I call the scholarship of engagement (Boyer, 1997, p. 11).

Boyer's charge to develop the scholarship of engagement challenges higher education to consider community involvement in a more active, deliberate fashion. In order to do so, higher education must "build important collaborative partnerships, improve all forms of scholarship,

Robert G. Bringle is professor of psychology, director, Center for Public Service and Leadership, and adjunct faculty, Philanthropic Studies, IUPUI; Julie A. Hatcher is associate director, Center for Public Service and Leadership, and adjunct instructor, School of Liberal Arts, Indiana University-Purdue University Indianapolis.

The Journal of Higher Education, Vol. 71, No. 3 (May/June 2000)

Copyright (C) 2000 by The Ohio State University 
nurture the support of stakeholders, and contribute to the common good" (Bringle et al., 1999, p. 12). Institutional changes that support the scholarship of engagement include intentionally clarifying mission in a manner that produces increased congruence between mission and practice, examining how the curriculum can better reflect community engagement, investing in infrastructure that supports community engagement, developing new models for assessing successful engagement in the community, and adjusting the roles and rewards of faculty so that faculty work in the community is recognized and supported (Bringle et al., 1999). When transformation of the work of colleges and universities on the scholarship of engagement occurs that is integral, enduring, and meaningful to all stakeholders, then service learning will be institutionalized.

Those in higher education engage in many types of service (e.g., to the disciplines, to students, to the institution). One of the most salient manifestations of the heightened attention to service has occurred in its integration with teaching in the form of service learning. Service learning is defined as a "course-based, credit-bearing educational experience in which students (a) participate in an organized service activity that meets identified community needs and (b) reflect on the service activity in such a way as to gain further understanding of course content, a broader appreciation of the discipline, and an enhanced sense of civic responsibility" (Bringle \& Hatcher, 1995, p. 112). Service learning is compatible with the renewed interest in developing the scholarship of engagement through collaborative work that is consistent with the mission of institutions (Boyer, 1997; Holland, 1997, 1999; Rice, 1996; Zlotkowski, 1999). Service learning engages students in active, relevant, and collaborative learning and is an effective way to enhance student learning, student development, and commitment to future civic involvement (Markus, Howard, \& King, 1993; Sax \& Astin, 1997). Thus, service learning is a smart choice for institutions of higher education because it enhances student achievement of core educational outcomes (Markus et al., 1993; Osborne, Hammerich, \& Hensley, 1998) and enhances faculty satisfaction with teaching (Hammond, 1994). Increasing the role of community service as a means for civic education also makes sense to the degree that it is a socially and morally responsible choice (Harkavy, 1996, 1998; Hatcher, 1997). As such, service learning is a good choice for institutions of higher education.

Many institutions are increasing emphasis on service as an integral aspect of higher education. To date, most programmatic efforts regarding service learning have been devoted to recruitment. For example, Campus Compact, a national organization created in 1985, has recruited 
more than 570 college presidents to bring service to the forefront of the agendas of their institutions (Rhodes, 1997). In addition, grant programs such as "Learn and Serve America" funded by the Corporation for National Service and "Integrating Service with Academic Study" funded by Campus Compact have been directed at recruiting faculty, students, and community partners to develop and implement service learning courses. These recruitment activities, however, need to be followed by different activities designed to develop each stakeholder so that their involvement in service learning is sustained as a meaningful part of their long-term interests (Bringle, Hatcher, \& Games, 1997). Only in this way will service learning become integrated into the broad spectrum of teaching, research, and service activities and an institutionalized component of higher education (Zlotkowski, 1996, 1999).

Thus, institutionalization of service learning is a multifaceted construct defined by the work and goals of several stakeholders (Morton \& Troppe, 1996). Institutionalization can be represented at the institutional level in a campus mission statement, presidential leadership, policy, publicity, budget allocations, broad administrative and staff understanding of and support for service learning, infrastructure, faculty roles and rewards, and service learning integrated with other aspects of institutional work (e.g., admissions, student affairs, financial aid, general education, long-term planning, institutional assessment). Among faculty, evidence of the institutionalization of service learning can be found in course and curriculum development, faculty development activities, expectations for recognition and rewards, broad faculty understanding of and support for service learning, and scholarship on service learning. For students, institutionalization of service learning is demonstrated through service and service learning scholarships, service learning classes, 4th credit options, student culture, and co-curricular transcripts that document service. Finally, community relationships provide evidence of institutionalization when agency resources are coupled with those of the academy to build reciprocal, enduring, and diverse partnerships that mutually support community interests and academic goals.

Campus Compact studied the degree of success among 44 institutions that attended Campus Compact planning institutes at which a team of administrators, faculty, and staff developed a campus plan for implementing service learning. The findings indicated that institutionalization is most likely when (a) congruence exists between institutional mission and strategic planning, (b) there is broad acceptance of the need for long-range planning and allocation of resources to support service learning, (c) faculty are central to planning, (d) incentives are provided to fac- 
ulty (e.g., course development stipends, release time), (e) faculty work is widely publicized, and (f) campus plans for integrating service into academic study evolve over time and across personnel (Morton \& Troppe, 1996).

Holland $(1997,1999)$ conducted case studies that examined the relationship between organizational factors and levels of commitment to community engagement. Her analysis led to delineating the following organizational factors as being relevant: mission; faculty promotion, tenure, and hiring; organizational structure to support community engagement; student involvement and integration of service into the curriculum; faculty involvement; community involvement; and publications and university relations. These factors provide a basis for assessing where a campus is, where they would like to be, and what activities would promote movement toward the desired degree of community engagement.

Other prior research on the institutionalization of service learning has been limited to qualitative analyses of small samples of institutions (e.g., Ward, 1996) and case studies (e.g., Hudson \& Trudeau, 1995; Troppe, 1996; Zlotkowski, 1998).

\section{Current Research}

The purpose of this research was to investigate the degree to which representatives from institutions of higher education reported the level of institutionalization of service learning on their campuses and to study some of the variables that were associated with differences in the institutionalization of service learning (Holland, 1997, 1999; Troppe, 1996; Ward, 1996). The current research also extended previous work by using an alternative means for conceptualizing and measuring the institutionalization of service learning. The Comprehensive Action Plan for Service Learning (CAPSL) provides a means for structuring strategic planning to implement service learning in higher education (Bringle \& Hatcher, 1996). In matrix form, the CAPSL model identifies four constituencies as being critical stakeholders in service learning (i.e., institution, faculty, students, community) and describes ten activities for each stakeholder that range from planning to institutionalization (see Table 1).

The activities identified in the CAPSL model are considered a heuristic that focuses attention on important steps of planned change and program development. The ten activities are listed in a sequential order. On the one hand, there is a rationale for suggesting that some steps (e.g., planning) should precede other steps (e.g., assessment). On the other hand, the ordering is presumed to be somewhat tenuous because, in practice, emphasis and effort may vary across the set of activities in a 
nonsequential manner. For example, planning would not be an event that occurred prior to all other activities and then, and only then, would the next activity occur. Thus, although the postulated sequence prioritizes activities, progress is assumed to vary across activities and within constituencies.

In addition to providing a framework for strategic planning, CAPSL is also a means for assessing, for each constituency, the developmental status of service learning on a campus (Bringle \& Hatcher, 1996). That is, evidence of more of these activities occurring for each of the constituencies is assumed to indicate the degree to which service learning is institutionalized on a campus. It was within this context that CAPSL was employed in the current research.

\section{Hypotheses}

Several hypotheses were generated based on previous work on implementing service learning and developing the CAPSL model (Bringle \& Hatcher, 1996). First, evidence for those activities identified earlier in the list (e.g., planning, awareness) were expected to be rated as having higher levels of achievement, to some degree, than the activities occurring later in the list (e.g., evaluation, research). Second, evidence of institutionalization was hypothesized to take place within the institution at a faster pace than it would with community relationships. This expectation was based on the assumption that implementing service learning at the institutional level (e.g., internal planning, developing infrastructure) would typically occur in preparation of and prior to establishing strong community partnerships.

TABLE 1

Comprehensive Action Plan for Service Learning (CAPSL)

\begin{tabular}{|c|c|c|c|c|}
\hline & Institution & Faculty & $\begin{array}{l}\text { Students } \\
\end{array}$ & $\begin{array}{l}\text { Community } \\
\end{array}$ \\
\hline \multicolumn{5}{|l|}{ Planning } \\
\hline \multicolumn{5}{|l|}{ Awareness } \\
\hline \multicolumn{5}{|l|}{ Prototype } \\
\hline \multicolumn{5}{|l|}{ Resources } \\
\hline \multicolumn{5}{|l|}{ Expansion } \\
\hline \multicolumn{5}{|l|}{ Recognition } \\
\hline \multicolumn{5}{|l|}{ Monitoring } \\
\hline \multicolumn{5}{|l|}{ Evaluation } \\
\hline \multicolumn{5}{|l|}{ Research } \\
\hline Institutionalization & & & & \\
\hline
\end{tabular}


Third, the degree of institutionalization of service learning was hypothesized to be associated with campus planning activities. Specifically, greater institutionalization would be associated with a campus team's participation in a Campus Compact planning institute. The fourth hypothesis was that a campus establishing a centralized office to support service learning would be associated with greater institutionalization than those campuses without a centralized office. This hypothesis was based on the Campus Compact findings that institutionalization was related to campus collaboration, planning, infrastructure, budget allocations, and faculty development-functions that can be centralized in a campus office (Morton \& Troppe, 1996). In addition, a centralized office improves campus collaboration and supports the recognition of service learning. Fifth, institutionalization was expected to be greater when a centralized office reported to an academic officer than other reporting arrangements (Bringle \& Hatcher, 1996, p. 230). The rationale for this hypothesis centered on the importance of faculty involvement and leadership in the development of service learning courses, the significance of promoting the academic integrity of service learning as curricular reform, and the credibility that an academic officer lends to discussions of service learning among faculty members. Finally, the research provided exploratory answers to how institutionalization of service learning was associated with various institutional characteristics.

\section{Methods}

\section{Questionnaire}

The questionnaire was based on the CAPSL model (Bringle \& Hatcher, 1996), which identifies (a) four constituencies and (b) ten activities (see Table 1). The questionnaire presented the CAPSL matrix and asked respondents to "rate the achievement that your institution has made in each of the cells in the grid." The response choices were $1=n o$ evidence of achievement, 2 = slight evidence of achievement, $3=$ clear evidence of achievement, and $4=$ clear evidence of substantial achievement. There were no further descriptions of each type of achievement. This allowed each respondent to appraise and describe their campus's progress without specifying the precise nature of activities that constituted the basis of the rating category for a cell (e.g., what constituted "slight achievement" of "increasing awareness of service learning" within "students"). In addition, respondents were asked to indicate total student population, institutional characteristics (check all that apply: private liberal arts, community college, Ph.D. granting, professional school, religious, commuter, residential, metropolitan, rural), whether or 
not the institution had a centralized office to coordinate service learning, how many years the office had been in existence, the administrative officer to whom the office reports, the percentage of funds for the office that came from internal campus resources, and whether or not (and when) the campus had participated in a Campus Compact planning institute.

\section{Procedure}

Questionnaires were distributed to those who attended the $1995 \mathrm{Na}-$ tional Gathering and the 1995 Colloquium on National Service. The National Gathering is an annual conference for faculty and staff interested in service learning. The 1995 National Gathering had 185 registrants. A second copy of the questionnaire was mailed after the conference to those registrants with an academic affiliation and who had not returned a questionnaire during the conference. Fifty questionnaires were completed by registrants of the National Gathering. Questionnaires were also mailed to registrants of the 1995 Colloquium on National Service co-sponsored by Campus Compact and American Association for Higher Education. The Colloquium on National Service was convened in response to President Clinton's letter sent in the fall of 1994 to every college and university president inviting them to inspire an ethic of service on their campus. The questionnaire was mailed to each registrant with an academic affiliation and the cover letter included instructions to complete and return the questionnaire or forward it to an appropriate person within the institution to complete and return. One hundred and twenty-nine questionnaires were returned by registrants of the Colloquium on National Service.

\section{Sample}

The 179 respondents from whom data were collected described their campuses in the following way: $45 \%$ were liberal arts colleges, $15 \%$ were community colleges, $26 \%$ were Ph.D. granting institutions, $14 \%$ were professional schools, $21 \%$ had religious affiliations, $44 \%$ were primarily commuter campuses (and 55\% were primarily residential), 35\% were metropolitan universities, and $17 \%$ were rural (more than one institutional category could be chosen).

Results

\section{Factors Associated With Institutionalization}

The marginal row means for the matrix show a pattern that supports somewhat the presumed linear nature of the steps from planning to institutionalization in the CAPSL model (see Table 2). Planning and aware- 
ness are among the highest means, evaluation and research are the lowest. A measure of institutionalization for each of the four constituencies (i.e., institution, faculty, students, community) was created by computing marginal means for each column of the matrix. This method of aggregating across the ten activities for each of the four constituencies was justified by good internal consistency within each constituency: institution (Cronbach's alpha $=0.94)$, faculty $(0.94)$, students $(0.93)$, and community (0.93).

Multivariate analyses of variance were conducted on the average institutionalization for each of the four constituencies (column means from CAPSL). Table 3 summarizes the results for those variables having significant multivariate effects for the four constituencies. Variables that did not have significant multivariate effects were the presence and absence of the following institutional characteristics: community college, PhD-granting, professional schools, residential, and rural. Commuter campus had a significant multivariate effect, but no significant univariate effects.

Campus Compact planning institute. Comparisons on the institutionalization of service learning were made between 158 respondents reporting that their campus had $(n=57)$ and had not $(n=101)$ attended a Campus Compact planning institute to integrate community service with academic study. Table 4 summarizes the results of those analyses. Attending a planning institute was associated with greater institutionalization of service learning for each constituency. However, length of time

TABLE 2

Cell and Marginal Means for CAPSL

\begin{tabular}{lccccc}
\hline \hline & Institution & Faculty & Student & Community & Row Mean \\
\hline Planning & 2.42 & 2.35 & 2.44 & 2.30 & 2.37 \\
Awareness & 2.68 & 2.62 & 2.58 & 2.34 & 2.56 \\
Prototype & 2.15 & 2.33 & 2.08 & 1.76 & 2.08 \\
Resources & 2.43 & 2.24 & 2.15 & 1.88 & 2.18 \\
Expansion & 2.45 & 2.47 & 2.56 & 2.30 & 2.45 \\
Recognition & 2.02 & 1.96 & 2.27 & 1.83 & 2.02 \\
Monitoring & 2.02 & 2.13 & 1.99 & 1.74 & 1.98 \\
Evaluation & 1.68 & 1.82 & 1.83 & 1.61 & 1.74 \\
Research & 1.50 & 1.79 & 1.51 & 1.31 & 1.53 \\
Institutionalization & 2.23 & 2.17 & 2.18 & 1.88 & 2.12 \\
Column Mean & 2.18 & 2.19 & 2.16 & 1.92 & \\
\hline
\end{tabular}


TABLE 3

Significant Effects for Institutional Characteristics

\begin{tabular}{|c|c|c|c|}
\hline & \multirow[b]{2}{*}{ Test of Significance } & \multicolumn{2}{|c|}{ Mean Difference } \\
\hline & & Yes & No \\
\hline Private Liberal Arts & Multivariate $F(4,159)=4.18^{*}$ & & \\
\hline Institution & ns & & \\
\hline Faculty & $F(1,162)=10.53 * *$ & 2.40 & 2.03 \\
\hline Students & $F(1,162)=4.38^{*}$ & 2.29 & 2.06 \\
\hline Community & $n s$ & & \\
\hline Religious & Multivariate $F(4,159)=3.29 *$ & & \\
\hline Institution & $F(1,162)=4.61^{*}$ & 2.43 & 2.12 \\
\hline Faculty & $F(1,162)=10.3^{* *}$ & 2.56 & 2.10 \\
\hline Students & $F(1,162)=4.69^{*}$ & 2.41 & 2.10 \\
\hline Community & $n s$ & & \\
\hline Commuter & Multivariate $F(4,159)=3.12^{*}$ & & \\
\hline Institution & $n s$ & & \\
\hline Faculty & $n s$ & & \\
\hline Students & $n s$ & & \\
\hline Community & $n s$ & & \\
\hline Metropolitan & Multivariate $F(4,159)=6.31^{* *}$ & & \\
\hline Institution & $n s$ & & \\
\hline Faculty & $F(1,162)=5.01^{*}$ & 2.37 & 2.10 \\
\hline Students & $n s$ & & \\
\hline Community & $n s$ & & \\
\hline
\end{tabular}

${ }^{*} p<0.05 . \quad{ }^{* *} p<0.01$

since attending the planning institute was not associated with significantly greater institutionalization.

Centralized office to coordinate service learning. Levels of institutionalization of service learning were examined by comparing those institutions that had established a centralized office for service learning ( $n$ $=100)$ to those without a centralized office $(n=61)$, with 18 not responding to the item. Table 5 summarizes the results of those analyses, which indicate that the presence of a centralized office was associated with greater institutionalization for all constituencies. The number of years that a centralized office had existed was also analyzed for the following groupings: 1 year or less $(n=35), 2-3$ years $(n=25)$, and 4 years or more $(n=35)$, with 5 not responding to the item. Significantly greater institutionalization was found for the four constituencies for those institutions that reported having a centralized office 2 years or longer (see Table 5).

Administrative position and funding of a centralized office. The administrative position to which the centralized office reported was also examined. The administrative positions were categorized into those that 
TABLE 4

Significant Effects for Attending a Campus Compact Planning Institute

\begin{tabular}{llcc}
\hline \hline & \multicolumn{2}{c}{ Mean Difference } \\
& Test of Significance & Yes & No \\
\hline CC Planning Institute & Multivariate $F(4,153)=2.84^{*}$ & & \\
Institution & $F(1,156)=5.87^{*}$ & 2.39 & 2.09 \\
Faculty & $F(1,156)=10.82^{* *}$ & 2.46 & 2.06 \\
Students & $F(1,156)=5.99^{*}$ & 2.35 & 2.06 \\
Community & $F(1,156)=4.31^{*}$ & 2.07 & 1.84 \\
\hline
\end{tabular}

${ }^{*} p<0.05 . \quad{ }^{* *} p<0.01$

clearly represented academic officers (e.g., president, provost, academic dean, dean of faculties, chancellor; $n=40$ ) or an administrator in student affairs (e.g., dean of student affairs, director of experiential education, director of college life, vice provost for student life; $n=49$ ). The 11 titles that could not be placed into one of these two categories were omitted from these analyses. Although the multivariate $F$ was only marginally significant $(p=0.07)$, three of the univariate $F$ s were significant and are reported in Table 5. The centralized offices of service learning that reported to the chief academic officers demonstrated greater institutionalization for the institution, faculty, and community. Whether or not the centralized office was supported by internal funds had a similar pattern (a marginally significant multivariate $F$ and three significant univariate $F s)$. Those institutions that had dedicated institutional funds to service learning $(n=71)$ showed greater institutionalization within the institution, among students, and with community partners than those that were supported by noninstitutional funds $(n=25)$.

\section{Discussion}

How can institutions develop the role of service learning on their campuses so that it becomes a meaningful aspect of faculty work, student life, institutional identity, and external partnerships? The results of this research suggest that some institutions (e.g., private liberal arts colleges, religious colleges, commuter campuses, metropolitan universities) are positioned to accomplish this more easily than others. However, these are not attributes that are malleable. The results also suggest that, across types of institutions, there are some important variables that imply steps that can be considered to increase the likelihood of institutionalizing service learning. First, institutionalization appears to benefit 
TABLE 5

Significant Effects for a Centralized Office

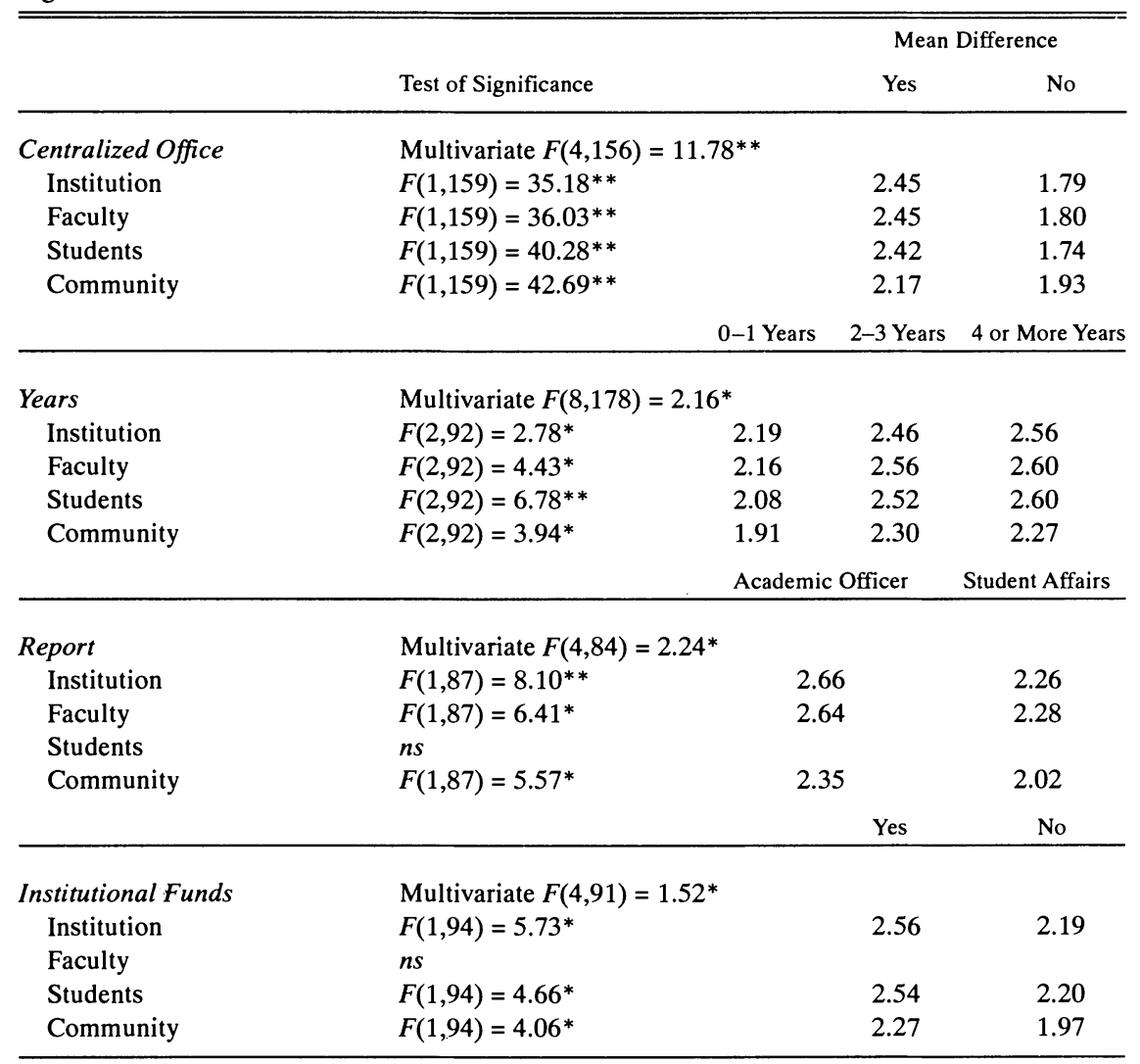

${ }^{*} p<0.05 . \quad{ }^{* *} p<0.01$.

from deliberate institutional planning. The results of this research suggest that institutions that sent a team to a Campus Compact planning institute, at which a team of administrators, faculty, and staff developed a campus plan for implementing service learning, reported greater institutionalization of service learning for all constituencies. Although there are alternative means for achieving the same outcome, this type of intensive planning institute appears to have facilitated the institutionalization of service learning. The lack of association between institutionalization and time since attending a Campus Compact planning institute may indicate that early steps following the planning institute were rapid (e.g., planning, awareness, prototype), but more substantial changes in the later rows of CAPSL occur more slowly. ${ }^{1}$ It could also indicate that at- 
tendance at the planning institute was the result of strong presidential leadership, but that lack of subsequent progress was due to the absence of key factors (e.g., broad-based faculty support, institutional commitments) (Morton \& Troppe, 1996).

The results also demonstrate the importance of developing campus infrastructure to support service learning. Hammond's (1994) research indicates that there are important obstacles identified by faculty who integrate service into the classroom (e.g., lack of time, lack of rewards, lack of recognition). Having a centralized office that provides technical assistance, logistical support, monetary incentives, and recognition is an important aspect of institutional infrastructure that can assist in the recruitment of second generation faculty to service learning. Bringle et al. (1997) have suggested that second generation faculty who consider incorporating service learning into their teaching will approach the work with a more pragmatic and less idealistic attitude than those who pioneered service learning. Such a centralized office can also support professional development of faculty who teach service learning classes, an issue that is important to ensuring that service learning becomes an enduring aspect of campus culture (Zlotkowski, 1996). Furthermore, identifying institutional responsibility with professional staff in a centralized office helps promote regular strategic planning, discussions about service learning in various forums on campus, assistance to faculty in documenting service learning in dossiers, regular recognition by faculty and administrators of the value of the work and outcomes resulting from service learning, and scholarship on service learning. Each of these functions is important support to second generation faculty members who have recently developed service learning courses (Bringle et al., 1997). Having a centralized office that is supported, to some degree, with institutional funds (as opposed to grant money) is an additional commitment by campus leadership that is associated with greater institutionalization. Morton and Troppe (1996) found that, since participating in a planning institute, $64 \%$ of campuses reported making budget commitments averaging $\$ 81,000$ per year. In this sample, for those institutions that had a centralized office, an average of $65 \%$ of their budget came from institutional funds.

The results of this research also support the expectation that placing a centralized office under the chief academic officer is advantageous to the institutionalization of service learning. There are many good service learning programs that are located within other reporting structures, and there are several reasons why service learning programs need to have strong collaborative working relationships with other units within the academy. The most important of these is student affairs, which typically 
administers structured, cocurricular service activities. However, the results of this research suggest that the degree of institutionalization of service learning on a campus benefits from the centralized office reporting to the chief academic officer, in contrast to alternatives. This academic leadership is assumed to be important to maintaining the integrity of service learning as a curricular activity and to promoting the value of service learning and community outreach in campus forums.

The confirmation of hypotheses and the ordering of the marginal means provides support for the construct validity of the CAPSL model. The results support the conclusion that the CAPSL model is a reasonable way in which to construe organizing strategic planning in order to develop service learning at institutions of higher education. The CAPSL model provides a broad framework that can be adapted to individual institutions as they implement and assess service learning programs (Bringle \& Hatcher, 1996). In addition, CAPSL provides one means through which the status of service learning can be assessed and meaningful comparisons among institutions can be made. There are many dimensions to institutionalization that can be considered in addition to those represented in the CAPSL matrix (e.g., recognition of service learning through budget allocations and faculty roles and rewards, civic education that is integrated into the curriculum, changed relationships between constituencies, service learning reflected in long-term institutional planning and assessment). However, the results suggest that the CAPSL matrix represents and measures some aspects of institutionalization and differentiates institutions in meaningful ways that are consistent with expectations.

\section{Limitations}

The current research is a preliminary step in systematically investigating the quantitative nature of the institutionalization of service learning among the four constituencies. However, the methods used in the current research have some inherent weaknesses that need to be considered when interpreting the results and planning subsequent research. Concerning the measurement of institutionalization, the current research had only one person's perspective or judgment about the degree of institutionalization of a campus. The validity of the measurement of institutionalization will be improved when judgments are aggregated across multiple judges. Future research will also benefit from obtaining judgments from representatives of all four constituencies. For example, the degree of institutionalization for students and community partners was solicited, but not from representatives of those constituencies. Judges were also given little information upon which to base their judgments 
about each of the activities and what constituted, for example, "substantial achievement." Improved judging protocols that anchor the types of activities and outcomes that represent "substantial improvement" will provide more valid characterizations of institutionalization.

Another limitation of the research is that it was cross-sectional and correlational and, therefore, causal inferences are difficult to make. For example, attending a Campus Compact planning institute was found to be associated with greater reported institutionalization. However, the degree to which campuses had achieved some critical level of commitment and institutionalization prior to the decision to attend the planning institute is not known. On the other hand, attending the planning institute and following through on a long-range campus plan might have enhanced the campus commitment and subsequent institutionalization. Or, it could be that other variables, such as strong campus leadership or campus culture, were compatible with integrating service into academic study because of shared values and clear mission, and these other factors resulted in taking multiple steps toward institutionalizing service learning, including attending a planning institute (Morton \& Troppe, 1996). Because the research was cross-sectional, it does not provide any evidence about which steps occurred prior to which campus changes, how and why campus culture to support service learning changed, or how obstacles to change were dealt with and overcome. Zlotkowski (1998) provides a rich set of case studies of exemplary service learning programs at ten colleges and universities that better illustrate these processes than does the current research.

The nature of the sample might also be a qualifying concern. Although the sample of institutions is not assumed to be representative, it is large and diverse. The data support the conclusion that these institutions were described as having only nominal institutionalization in 1995. The grand mean for the institutionalization of service learning (grand mean $=2.11$ ) indicates that the institutions were characterized as being relatively early in the process of institutionalizing service learning ("slight evidence of achievement"). Furthermore, although two-thirds of the respondents reported centralized offices for service learning, most of these offices were less than four years old.

Concerning the respondents who completed the survey, they were generally knowledgeable about the status of service learning on their respective campuses. Even though the respondent might have been a practitioner and advocate for service learning or someone delegated by the campus president to attend the National Colloquium to investigate increasing future campus involvement, we assume that, in either case, they had little reason to give biased responses. 


\section{Implications}

The CAPSL model can be used as both an initial and an ongoing planning heuristic and as a framework for program evaluation and research. For example, we have asked different stakeholders on our campus to complete the CAPSL model using a response format similar to the one employed in the current research. In addition, respondents were asked to circle one cell in each column that they thought should be our highest priority as we developed the next year's programs. Asking representatives from various stakeholders (e.g., students, community representatives, deans, faculty governance) to complete this exercise provides information about convergence and variability in perceptions of service learning on a campus, perceived strengths, and information about planning priorities across and within constituencies.

The nature of the CAPSL model also argues for balanced programming across constituencies. CAPSL can be used to identify neglected areas that deserve programmatic attention. This would occur in the form of low ratings for a column. Alternatively, CAPSL can identify discrepancies in the characterization of institutionalization by one constituency compared to another (e.g., faculty perceive lower awareness among community than community representatives report for themselves). Furthermore, discrepancies between assessment by staff most directly involved with service learning and a constituency (e.g., students report less progress on awareness than staff assumed) also identifies programmatic issues to be addressed.

Although many campuses have now recruited commitments among faculty, staff, students, administrators, and community partners that are necessary to offer service learning courses, CAPSL suggests additional steps for a campus to take in order to build on these successes. For example, collecting campuswide as well as course-specific data to monitor service learning provides information that allows quality control, identifies areas for improvement, and creates benchmarks against which progress can be judged. Expanding this data collection to outcome measures that provide the basis for scholarship on service learning further extends participation in reflective practice on a campus and, through presentations and publications, extends the understanding of service learning among those on other campuses.

Significant achievement in all of the rows in CAPSL is assumed to represent a degree of maturity for the institutionalization of service learning. However, this level of success with service learning can be viewed as just one component of a broader agenda proposed by Boyer as the scholarship of engagement and the model of the new American col- 
lege (Boyer, 1994, 1997; Bringle et al., 1999; Glassick, 1999). As such, community engagement presents broader challenges not only for enhancing the curriculum (e.g., interdisciplinary courses, sequenced service learning courses, coherent integration into general education) but also for clarifying mission, developing broad-based institutional support for community engagement, reconceptualizing scholarship and its assessment and recognition through faculty roles and rewards, providing better community input into higher education, and assessing institutional success (e.g., achieving mission, student learning, civic education, positive community impact) (Bringle et al., 1999).

\section{Conclusion}

The current research was designed to demonstrate that institutionalization of service learning could be meaningfully measured using the CAPSL model and that the measure could be used as a basis for investigating factors associated with institutionalization. This is an important step, but only a first step. Presidents, especially those whose membership in Campus Compact indicates a commitment to support service as an integral aspect of higher education, can now be challenged to take the next steps to follow through on that commitment to ensure that service learning and community engagement are integrated in the work and culture of the academy. The results of this research suggest what some of these steps should be: (a) conducting regular strategic planning; (b) establishing and developing a centralized office not only to recruit but also to develop each of the four constituencies; (c) increasing institutional budget commitments to support the development of service learning; and (d) vesting the commitment to service learning with leadership that establishes and maintains its academic integrity.

Note

${ }^{1}$ We extend our appreciation to an anonymous reviewer for suggesting this interpretation.

\section{References}

Boyer, E. L. (1994, March 4). Creating the new American college. Chronicle of Higher Education, p. A48.

Boyer, E. L. (1997). The scholarship of engagement. Journal of Public Service and Outreach, 1(1), 11-20.

Bringle, R. G., Games, R., \& Malloy, E. A. (1999). Colleges and universities as citizens. Boston: Allyn \& Bacon. 
Bringle, R. G., \& Hatcher, J. A. (1995). A service-learning curriculum for faculty. Michigan Journal of Community Service Learning, 2, 112-122.

Bringle, R. G., \& Hatcher, J. A. (1996). Implementing service learning in higher education. Journal of Higher Education, 67, 221-239.

Bringle, R. G., Hatcher, J. A., \& Games, R. (1997). Engaging and supporting faculty in service learning. Journal of Public Service and Outreach, 2(1), 43-51.

Eggerton, R. (1994). The engaged campus: Organizing to serve society's needs. AAHE Bulletin, 47, 2-3.

Glassick, G. E. (1999). Ernest L. Boyer: Colleges and universities as citizens. In R. G. Bringle, R. Games, \& E. A. Malloy (Eds.), Colleges and universities as citizens (pp. 17-30). Boston: Allyn \& Bacon.

Hammond, C. (1994). Integrating service and academic study: Faculty motivation and satisfaction in Michigan higher education. Michigan Journal of Community Service Learning, 1, 21-28.

Harkavy, I. (1996). Back to the future: From service-learning to strategic academically based community service as an approach for advancing knowledge and solving the problem of the American city. Metropolitan Universities, 7, 157-170.

Harkavy, I. (1998, June 19). The institutional service role. Paper presented at the National Invitational Conference on Higher Education and Civic Responsibility, Tallahassee, FL.

Harkavy, I., \& Puckett, J. L. (1994). Lessons from Hull House for the contemporary urban university. Social Science Review, 68, 299-321.

Hatcher, J. A. (1997). The moral dimensions of John Dewey's philosophy: Implications for undergraduate education. Michigan Journal of Community Service Learning, 4, 22-29.

Holland, B. A. (1997). Analyzing institutional commitment to service: A model of key organizational factors. Michigan Journal of Community Service Learning, 4, 30-41.

Holland, B. A. (1999). From murky to meaningful: The role of mission in institutional change. In R. G. Bringle, R. Games, \& E. A. Malloy (Eds.), Colleges and universities as citizens (pp. 48-73). Boston: Allyn \& Bacon.

Hudson, W. E., \& Trudeau, R. H. (1995). An essay on the institutionalization of servicelearning: The genesis of the Feinstein Institute for Public Service. Michigan Journal of Community Service Learning, 2, 150-158.

Markus, G. B., Howard, J. P. F., \& King, D. C. (1993). Integrating community service and classroom instruction enhances learning: Results from an experiment. Educational Evaluation and Policy Analysis, 15, 410-419.

Morton, K., \& Troppe, M. (1996). From the margin to the mainstream: Campus Compact's project on Integrating Service with Academic Study. Journal of Business Ethics, 15, 21-32.

Osborne, R. E., Hammerich, S., \& Hensley, C. (1998). Student effects of service-learning: Tracking change across a semester. Michigan Journal of Community Service Learning, 5, 5-13.

Rhodes, N. (1997). Campus Compact: The project for public and community service. Journal of Public Service and Outreach, 2(1), 56-61.

Rice, R. E. (1996, January). Making a place for the new American scholar. Paper presented at the AAHE Conference on Faculty Roles and Rewards, Atlanta, GA. 
Sax, L. J., \& Astin, A. W. (1997). The benefits of service: Evidence from undergraduates. Educational Record, 78(3/4), 25-32.

Troppe, M. (1996). Two cases of institutionalizing service learning: How campus climate affects the change process. Providence, RI: Campus Compact.

Ward, K. (1996). Service-learning and student volunteerism: Reflections on institutional commitment. Michigan Journal of Community Service Learning, 3, 55-65.

Zlotkowski, E. (1996). Linking service-learning and the academy: A new voice at the table? Change, 28(1), 21-27.

Zlotkowski, E. (1998). Successful service-learning programs: New models of excellence in higher education. Boston: Anker.

Zlotkowski, E. (1999). Pedagogy and engagement. In R. G. Bringle, R. Games, \& E. A. Malloy (Eds.), Colleges and universities as citizens (pp. 96-120). Boston: Allyn \& Bacon. 